\title{
Review on Solid Waste Generation and Management in Sub-Saharan Africa: A Case Study of Nigeria
}

\author{
*1ORHORHORO, EK; ${ }^{2}$ OGHOGHORIE, O
}

\author{
${ }^{I}$ Department of Mechanical Engineering, College of Engineering, Igbinedion University, Okada, Nigeria \\ ${ }^{2}$ Department of Mechanical Engineering, Faculty of Engineering, Benson Idahosa University, Benin City, Nigeria \\ *Corresponding Author Email: ejiroghene.orhorhoro@iuokada.edu.ng; Tel: +2348064699781
}

\begin{abstract}
Nigeria just likes every other country in sub-Sahara Africa is faced with solid waste generation and management. Solid waste is dump indiscriminately and seen in huge heaps on any piece of unused land, around buildings, drainage system, institutions, playing ground, roads side, and in the open market places in major cities and towns. Living with solid wastes littered around seems to be an acceptable way of life among the people in this part of the world. This research work reported intensive review on solid wastes generation and management in this region using Nigeria as a case study. The application of knowledge of solid waste generation and management approach is crucial for inculcating a change of attitude towards improving the management of generated solid waste in this region. From the review, it was observed that biodegradable solid waste that can be managed via the biogas technology and landfill technology have the highest percentage fraction while the remaining fraction that comprised of non-biodegradable and combustible solid waste can be managed via other technology such incineration, gasification, pyrolysis, etc. Besides, the inefficient management of generated solid waste by individuals, households, institution, consumers and waste management companies can be attributed to inadequate information on waste management benefits, insufficient academic research and industry linkages, financial constraint, economic constraint, cultural constraint, lack of planning and projection, social constraint, lack of producers' involvement in waste management as well as poor implementation of government policies and lack of comprehensive legal framework.
\end{abstract}

\section{DOI: https://dx.doi.org/10.4314/jasem.v23i9.19}

Copyright: Copyright $(\mathbb{C} 2019$ Orhorhoro and Oghoghorie. This is an open access article distributed under the Creative Commons Attribution License (CCL), which permits unrestricted use, distribution, and reproduction in any medium, provided the original work is properly cited.

Dates: Received: 03 August 2019; Revised: 05 September 2019; 21 September 2019

Keywords: Solid waste generation, solid waste management, biodegradable solid waste, combustible solid waste

Solid waste is the useless and unwanted substances in solid state, discarded by members of the society. It can be defined as any product or substance that has no further use or value for the person or organization that owns it, and which is or will be discarded (Kolekara et al., 2016). Solid waste can be classified based on their source, such as; municipal solid waste, industrial solid waste and agricultural solid waste. Solid waste generation and management are major problems facing sub-Sahara Africa countries like Nigeria, Ghana, Cameroon, etc. Most cities and towns in this region spend $20-50 \%$ of their environmental budget on solid waste management and only $20-80 \%$ of the waste is collected. The standard of waste management in sub-Sahara Africa countries is at its lowest with inefficient storage and collection system, and the under-utilization of disposal sites. Thus, solid waste disposal has become a menace in sub-Sahara Africa countries because of their poor waste management policy. In nook and cranny of the major cities and towns in sub-Sahara Africa countries, one can see a rotting heap of solid waste in open places such as; markets, institutions, streets, drainage system, uncompleted buildings, etc. (Orhorhoro et al., 2016b). Poor management of solid waste in sub-Sahara Africa countries is a source of concern to the society. The generated waste poses a threat to urban management, defaces the aesthetics of the country's cities and towns (Fig. 1), and a health hazard to citizens through the blockage of drainage systems, causing erosion and flooding. It is a breeding ground for mosquitoes, thus, posing a serious health risk to the populace sub-Sahara Africa countries.

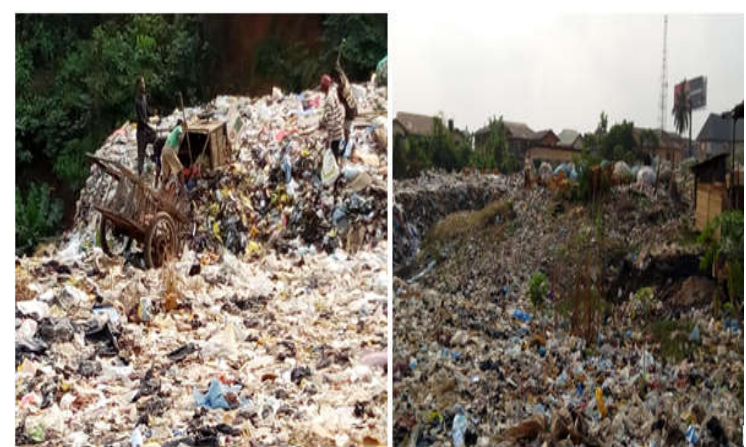

Fig. 1: Open dumpsite, Benin City, Nigeria 
In this research work, a comprehensive review on solid waste generation and management was carried out in Nigeria being the most populated country in that region. The quantity of solid waste generated in Nigeria is increasing because of increase in her population that is estimated at $187,896,647$ persons. Nigeria accounts for nearly half the total population of West Africa, and more than $15 \%$ of the total population of African. The population density in Nigeria is 205 per $\mathrm{Km}^{2}$, and the total land area is $910,802 \mathrm{Km}^{2}$. Estimated $48.1 \%$ of the population live in urban while the rest based in the rural area with farming as their major occupation. Nigeria population is equivalent to $2.48 \%$ of the total world population and is estimated to double that figure by the year 2050 (UNWPE, 2016). As a result of the quantity of solid waste generated from Nigeria cities and towns due to poor implementation of standards and lack of proper waste management policy, strategic centers of attraction in Nigeria are sometimes taken over by the messy nature of unattended heaps of solid wastes emanating from the society (Fig. 2) (Anwar et al., 2014; Orhorhoro et al., 2017a). City officials and town planners appear unable to combat unlawful dumping of solid waste, which is a clear violation of the clean Air and Health Edicts in environmental sanitation laws and regulations (Akintokun et al., 2011; Antanasijevic et al., 2013).

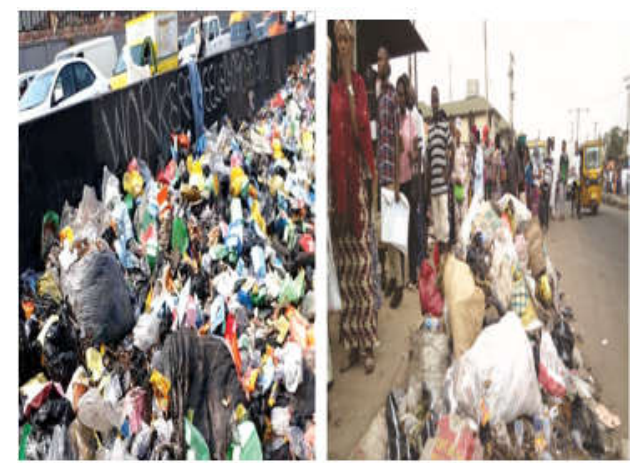

Fig. 2: Solid waste dump in major road, Lagos State, Nigeria
Solid Waste Generation: Solid waste is generated in all sorts of ways. However, the volume of solid wastes generated in Nigeria mainly depends on the consumption pattern, industrial and economic structures in place (Orhorhoro, 2014). According to Hoornweg and Bhada-Tata (2013), countries with fast growing economies are mostly faced with high volume of solid waste generation. For example, waste generated in China increased 9\% annually from 1979 to 1995 , a period associated with rapid economic growth, and this is expected to double by 2030 (Forbes Economy ranking in Africa in 2018). Nigeria has the best economy in Africa with an estimated $\$ 172$ billion, followed by South Africa with $\$ 166.735$ billion. Thus, if the report of Hoornweg and Bhada-Tata (2013) is anything to go by, more solid waste will be generated in Nigeria and this call for concern. Besides, different research work carried out in Nigeria to determine and evaluate the quantity of solid waste generated per day shown that Nigeria solid waste generation is at a daily rate of $0.43-0.66 \mathrm{~kg} / \mathrm{capital} /$ day (Table 1 ).

Globally solid waste generation levels are approximately 1.3 billion tonnes per year and this is expected to increase by 2.2 billion tonnes per year by 2025. This represents a significant increase in per capital solid waste generation rates, from 1.2 to 1.42 $\mathrm{kg}$ per person per day in the next fifteen years (Igbinomwanhia, 2011a; Igbinomwanhia et al., 2011b; Hoornweg et al., 2013). Table 2 shows solid waste generation per capita by region, indicating the lower boundary and upper boundary for each region, as well as average $\mathrm{kg}$ per capita per day of waste generated within each region. Solid wastes generation in subSaharan Africa is approximately 62 million tonnes per year and it spans a wide range from 0.09 to $3.0 \mathrm{~kg}$ per person per day with an average of $0.65 \mathrm{~kg} /$ capital/day (Hoornweg et al., 2014). Figure 3 shows global waste generation per region. Table 3 shows estimates of solid waste generation for the year 2025 as expected according to current trends in population growth in each region.

Table 1: Solid wastes generation in some major urban cities and towns in Nigeria (Igbinomwanhia, 2011a; Hoornweg et al., 2014; Titus,

\begin{tabular}{llllll}
\multicolumn{5}{c}{ and Anim, 2014; Owamah et al., 2015; Igbinomwanhia et al., 2017; Orhorhoro et al., 2017a) } \\
\hline City & Population & Agency & $\begin{array}{l}\text { Tonnage } \\
\text { per } \\
\text { Month }\end{array}$ & $\begin{array}{l}\text { Density } \\
\left(\mathrm{kg} / \mathrm{m}^{3}\right)\end{array}$ & $\begin{array}{l}\text { kg per } \\
\text { capita } \\
\text { per day }\end{array}$ \\
\hline Benin & $1,085,676$ & & - & - & 0.43 \\
Lagos & $8,029,200$ & Lagos state management authority & 255,556 & 294 & 0.63 \\
Kano & $3,348,700$ & Kano state environmental protection agency & 156,676 & 290 & 0.56 \\
Ibadan & 307,840 & Oyo state environmental protection commission & 135,391 & 330 & 0.51 \\
Kaduna & $1,458,900$ & Kaduna state environmental protection agency & 114,443 & 320 & 0.58 \\
Port Harcourt & $1,053,900$ & Rivers state environmental protection agency & 117,825 & 300 & 0.60 \\
Makurdi & 249,00 & Urban development board & 24,242 & 340 & 0.48 \\
Onitsha & 509,500 & Anambra state environmental protection agency & 84,137 & 310 & 0.53 \\
Nsukka & 100,700 & Enugu state environmental protection agency & 12,000 & 370 & 0.44 \\
Abuja & 159,900 & Abuja state environmental protection agency & 14,785 & 280 & 0.66 \\
\hline \multicolumn{7}{c}{} & &
\end{tabular}


Table 2: Solid waste generation per capita by region (Hoornweg et al., 2013)

\begin{tabular}{|c|c|c|c|}
\hline \multirow[t]{3}{*}{ Region } & \multicolumn{3}{|c|}{$\begin{array}{c}\text { Waste Generation Per Capita } \\
\text { (kg/capita/day) }\end{array}$} \\
\hline & Lower & Upper & Average \\
\hline & Boundary & Boundary & \\
\hline *Sub-Sahara Africa (S.AF) & 0.09 & 3.0 & 0.65 \\
\hline East Asia Pacific (EAP) & 0.44 & 4.3 & 0.95 \\
\hline Southern Asia (SA) & 0.12 & 5.1 & 0.45 \\
\hline OECD member countries & 1.10 & 3.7 & 2.2 \\
\hline Middle East and North Africa (MENA) & 0.16 & 5.7 & 1.1 \\
\hline Latin America and the Caribbean (LAC) & 0.11 & 5.5 & 1.1 \\
\hline East and Central Asia (ECA) & 0.29 & 2.1 & 1.1 \\
\hline
\end{tabular}

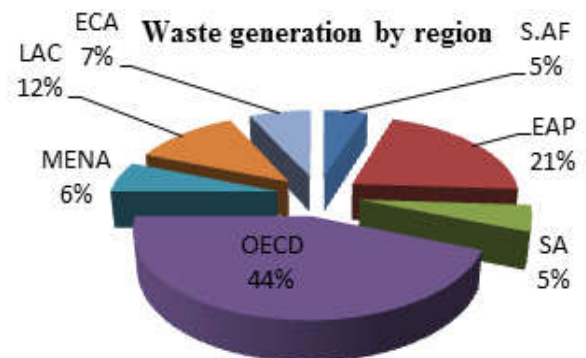

Fig. 3: Solid waste generation by region (Hoornweg et al., 2014)

Table 3: Solid wastes generation projections for 2025 by region (Hoornweg et al., 2014)

\begin{tabular}{|c|c|c|c|c|c|c|c|}
\hline \multirow[t]{3}{*}{ Region } & \multicolumn{3}{|c|}{ Current Available Data } & \multicolumn{4}{|c|}{ Current Available Data Projections for 2025} \\
\hline & \multirow{2}{*}{$\begin{array}{l}\text { Total Urban } \\
\text { Population } \\
\text { (millions) }\end{array}$} & \multirow{2}{*}{$\begin{array}{l}\text { Urban Solid } \\
\text { Per Capital } \\
\text { (kg/capita } \\
\text { /day) }\end{array}$} & \multirow{2}{*}{$\begin{array}{l}\text { Waste Generation } \\
\text { (Tons/ } \\
\text { day) }\end{array}$} & \multicolumn{2}{|c|}{ Projected Population } & \multicolumn{2}{|c|}{ Projected Urban Solid Waste } \\
\hline & & & & $\begin{array}{l}\text { Total Population } \\
\text { (millions) }\end{array}$ & $\begin{array}{l}\text { Urban Population } \\
\text { (millions) }\end{array}$ & $\begin{array}{l}\text { Per Capita (kg/ } \\
\text { capita/day) }\end{array}$ & $\begin{array}{l}\text { Total } \\
\text { (tons/day) }\end{array}$ \\
\hline *S.AF & 260 & 0.65 & 169,119 & 1,152 & 518 & 0.85 & 441,840 \\
\hline EAP & 777 & 0.95 & 738,958 & 2,124 & 1,229 & 1.5 & $1,865,379$ \\
\hline $\mathrm{ECA}$ & 227 & 1.1 & 254,389 & 339 & 239 & 1.5 & 354.810 \\
\hline LAC & 399 & 1.1 & 437,545 & 681 & 466 & 1.6 & 3728,92 \\
\hline MENA & 162 & 1.1 & 173,545 & 379 & 257 & 1.43 & 369,320 \\
\hline OECD & 729 & 2.2 & $1,566,286$ & 1,031 & 842 & 2.1 & $1,742,417$ \\
\hline SA & 426 & 0.45 & 192,410 & 1,938 & 734 & 0.77 & 567,545 \\
\hline Total & 2,980 & 1.2 & $3,532,252$ & 7,644 & 4,285 & 1.4 & $6,069,703$ \\
\hline
\end{tabular}

Sources of Solid Wastes in Nigeria: The various sources of solid waste generated in Nigeria are summaries in Table 4.

Solid Waste Characterization: Solid waste characterization can be defined as the process by which the composition of different solid waste stream is grouped and analyzed (Sabejeje et al., 2014). Solid waste is heterogeneous in composition; thus, it is not expected to be consistent in composition. Several researchers reported different composition of solid waste generated in Nigeria as depicted in Fig. 4 (Oyelola, and Babatunde, 2008; Igbinomwanhia et al., 2011b; Owamah et al., 2015; Orhorhoro et al., 2017a). Organic solid waste account for over $50 \%$ of solid waste generated in Nigeria cities and towns with other solid waste components such as metals, plastic, leather waste, etc. estimated at different composition (Fig. 4). Solid wastes generated in Nigeria cities and towns generally consist of food remnants, plastics, paper, textile, metal, glass (Orhorhoro et al., 2017a). Igbinomwanhia (2011a) carried out research work on the status of waste management using Mushin Local Government Area, Lagos State, and Oredo Local Government Area, Benin, Edo State, both a major cities located in Nigeria. The selected areas for his research work are located at the geographical center of Lagos and Benin metropolis. A total weekly average of $2263.2 \mathrm{Kg}$ of domestic solid waste was generated in Lagos metropolis within the period of study. Based on this figure, a daily generation rate of $0.57 \mathrm{~kg}$ per person per day (ppd.) was calculated for Lagos metropolis. Besides, a total $5373.61 \mathrm{Kg}$ of domestic solid waste was generated within the period in Benin metropolis, Nigeria. Base on this figure, a daily generation rate of $0.425 \mathrm{~kg}$ per person per day (ppd.) was determined and evaluated. The percentage composition of solid waste generated was similar to the one obtained in other major cities and towns across Nigeria (Zavodska, 2003; Owamah et al., 2015; Orhorhoro et al., 2017a). Also, in the research work carried out by Igbinomwanhia et al. (2017) entitled "Characterization of Domestic Solid Waste for the Determination of Waste Management Option in 
Amassoma, Bayelsa State, Nigeria"; the results obtained revealed that the total solid waste generated in Amassoma is $1115.2 \mathrm{~kg} /$ day from domestic activities. Besides, analysis of the collected samples showed that $51.34 \%$ of compostable waste (garbage) which is biodegradable is generated, $33.62 \%$ of combustible waste and $15.04 \%$ of incombustible waste is generated in Ammasoma town. Their study also revealed that open dumpsite is the current solid waste disposal option in Amassoma. Although, engineering landfill could have been preferable to the open dumpsite but because of the geography of Amassoma being located in oil prone Niger Delta of Nigeria that is largely covered with water, if landfill system is adopted, it can lead to eutrophication. For that reason, they recommended integrated waste management programme incorporating recycling, composting and incineration with energy recovery.

Table 4: Sources of solid wastes generated in Nigeria (Benjamin et al., 2014; Ukwaba et al., 2018)

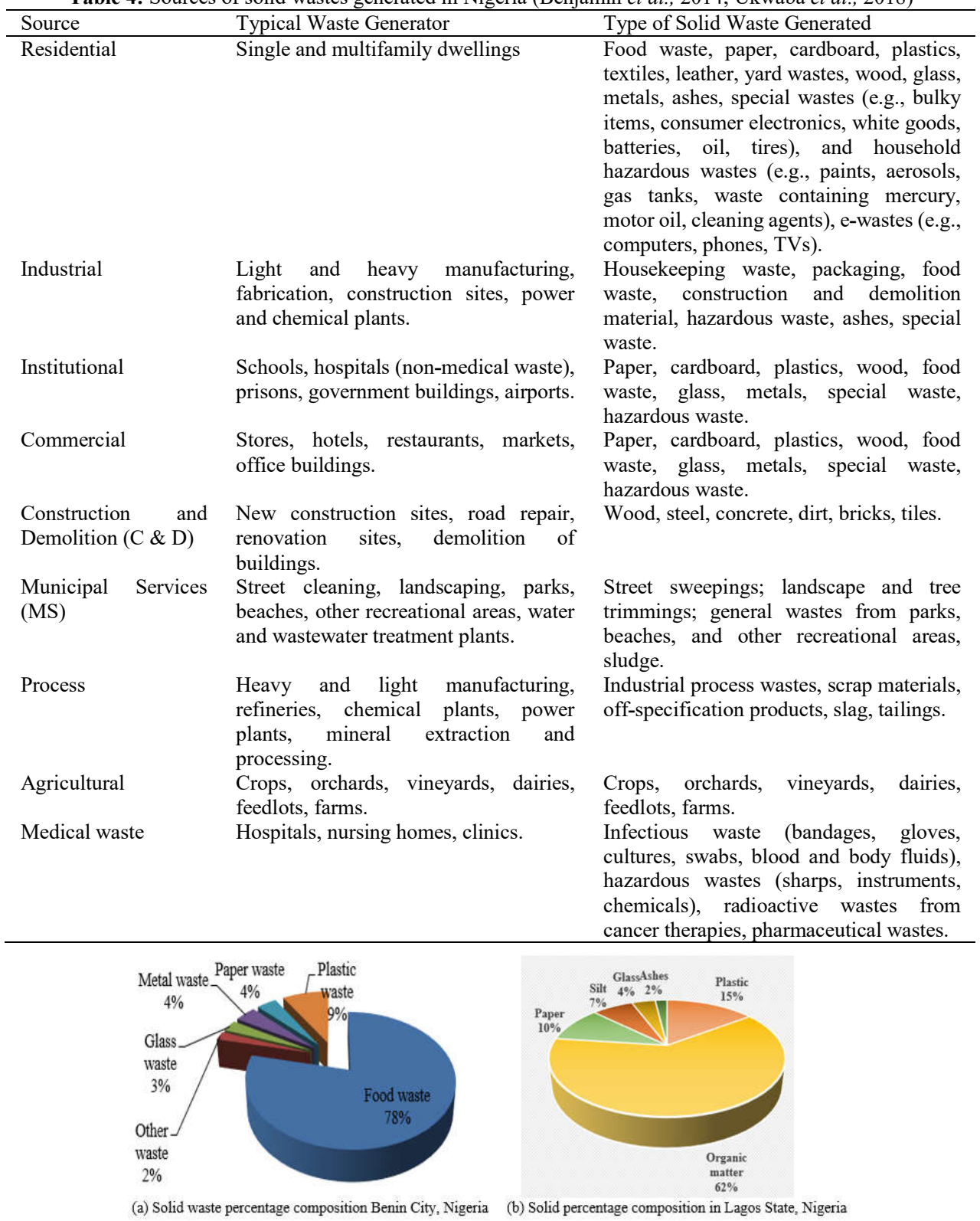

Fig. 4: Solid waste percentage composition generated daily in Nigeria cities and towns

Solid Waste Management: Solid waste management simply means all waste activities that are required to manage generated solid wastes effectively. It includes generation, control, storage, collection, transfer and transportation, processing and disposal of solid waste consistent with the best practices of public health, 
economics and finance, engineering, administration, legal and environmental considerations (Orhorhoro et al., 2017a). Fisher et al. (2015) defined solid waste management as the collection, transportation, recovery, recycling and disposal of waste, as well as the supervision of such operations and the after care of disposal sites including actions taken as a dealer or broker. Solid waste problem started in Nigeria with the rapid increase in urban growth resulting partly from the increase in population status. There is no town in Nigeria being in rural or urban area that can boast of finding a lasting solution to the problem of filth and huge piles of solid wastes. In Nigeria, solid wastes are dumped indiscriminately, and this has led to blockage of drainages, thus causing environmental pollution (Ogwueleka, 2009). The commonly practiced solid waste management option in Nigeria involves the collection of mixed wastes from houses, restaurants, institutions, industries, markets, etc. and subsequent dumping it at designated open dumpsites (World Bank, 1999). This practice in Nigeria contradicts the concept of integrated solid waste management (Reduction, Recycle, Reuse, Energy Recovery, Final disposal) (Orhorhoro et al., 2018b). To average Nigerians, public hygiene starts and ends in their immediate surrounding and indeed the city would take care of itself. The situation has so deteriorated that today the menace of solid waste has become one of the nation's most serious environmental problems.

Furthermore, because of the inadequate coverage of most urban cities, towns and rural areas of the country by the waste management agencies during waste collection services, residents resort to dumping of refuse along the road and any available space (Ogwueleka, 2009). World Bank (1999) reported that waste generation can be an asset in terms of wealth creation and job opportunities when properly manage but can also be a curse when managed improperly, thus, constituting hazards to public health and surrounding environment. For instance, open dumpsites are located near streams and rivers while solid waste is sometimes dumped in rivers in Nigeria which serve as major sources of drinking water to residents, particularly in the rural areas (Pereira et al., 2012). By so doing, the liquid content generated by biodegradable waste during decomposition can migrate into or percolate through the soil to contaminate surface and ground water, thereby making it unfit for drinking. Besides, PET bottles and other non-biodegradable materials from open dumpsites end up blocking drainage systems during raining season (Oziegbe, 2015; Orhorhoro et al., 2016a).
Solid Waste Management Hierarchy: Solid waste management hierarchy is shown in Fig. 5. If Nigeria can adopt the integrated solid waste management programme, the large volume of generated solid waste can be channeled into energy generation and other usage, thus making the environment friendly and healthy.

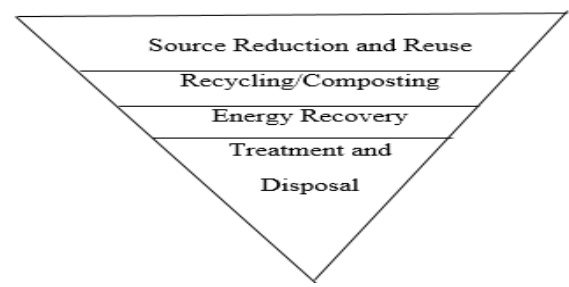

Fig. 5: Waste management hierarchy

Source Reduction and Reuse: Source reduction and reuse are solid waste management practice that encompasses all the activities premeditated to reduce the volume of solid waste generated, or toxicity of products throughout their life cycle. It involves the design and manufacture, use and disposal of products with minimum toxic content, minimum volume of material and/or a longer useful life. It takes various forms such as reusing or donating items, buying in bulk, reducing packaging, redesigning and reducing products (Oziegbe, 2015). According to McKendry (2002), specific examples of source reduction include:

i. The redesigning of products to use fewer materials (material substitution).

ii. Reusing products and materials that have served the main purpose it was meant for (e.g., a refillable water bottle).

iii. Extending the useful lifespan of products.

The following benefits can be obtained from source reduction and reuse (McKendry, 2002):

i. It helps in savings natural resource.

ii. It brings about conservation of energy.

iii. It helps in the reduction of pollution.

iv. It brings about reduction in the toxicity of wastes.

Recycling/Composting: Solid waste recycling/composting is a waste management technology that converts solid wastes to reusable products. It involves activities such as collection of used, reused, or unused items that have been discarded and processing of it into usable products (Kreiger et al., 2014).

Energy Recovery: Energy recovery from solid wastes is the conversion of non-recyclable wastes materials into usable heat, electricity, or fuel through a variety of processes/technologies (i.e., combustion, 
gasification, pyrolysis, etc.). This process is often called waste-to-energy (WTE). Energy recovery serves two major purposes (i.e., wastes control and energy production) (Thomson, 2010).

Treatment and Disposal: Landfills are the most common form of waste disposal. However, in Nigeria, lack of engineering landfill system, encourages open dumpsites as means of waste management. Landfill is an important component of an integrated waste management system. Landfills that accept municipal solid wastes are primarily regulated by state and local governments. Today's landfills must meet stringent design, operation and closure requirements. Biomethane of the landfill system can be collected and used as fuel. After a landfill is capped, the land may be used for recreation sites such as parks, golf courses, etc.

Biochemical Technology: Biochemical technology involves the breakdown of hemicellulose fraction. The two biochemical process options are anaerobic digestion (AD) and aerobic fermentation (Orhorhoro et al., 2016a; Orhorhoro et al., 2018a). In AD process, high moisture content $(85-90 \%)$ biomass is converted into biogas by microorganisms in the absence of oxygen (Orhorhoro et al., 2017b; Orhorhoro et al., $2017 \mathrm{bc}$ ). The raw biogas is purified before it can be used, and this is because of the presence of impurities such as hydrogen sulphide, dust, water, siloxane and halogenates hydrocarbons. These impurities if not removed can cause health problems, corrosion problems in processing, handling and storage facilities/equipment (Orhorhoro et al., 2018a).

Thermochemical Conversion of Solid Waste: Thermochemical conversion of solid waste embroils any of the following processes: combustion, gasification, pyrolysis (Lim et al., 2012). Combustion is used mostly for biomass with moisture content less than $50 \%$. It converts the chemical energy stored in biomass into heat, mechanical power or electricity in stoves, furnaces, boilers, steam turbines or turbo generators. The combustion technology is either fixed bed or fluidized bed systems. Solid waste can be cofired in existing coal power plants or combusted in a dedicated combined heat and power (CHP) plants.

Gasification: Gasification is the conversion of the generated solid waste into combustible gas mixture by the partial oxidation of the waste at temperatures of about $800^{\circ} \mathrm{C}-900^{\circ} \mathrm{C}$ under a controlled amount of air. The produced gases consist of a mixture of carbon monoxide (CO) (18-20\%), hydrogen $\left(\mathrm{H}_{2}\right)(18-20 \%)$, carbon dioxide $\left(\mathrm{CO}_{2}\right)(8-10 \%)$, methane $\left(\mathrm{CH}_{4}\right)$ $3 \%$ ), small quantities of other light hydrocarbons
$\left(\mathrm{C}_{5} \mathrm{H}_{10}\right)$ and steam $\left(\mathrm{H}_{2} \mathrm{O}\right)$ including nitrogen $\left(\mathrm{N}_{2}\right)$. The produced gases have low calorific value (4-6 MJ/Nm ${ }^{2}$ ) and can burnt directly or used as a fuel for gas engines and gas turbines. The composition of the gas is influenced by gasification conditions such as temperature and pressure (El-Emam et al., 2012).

Pyrolysis: Pyrolysis is a thermochemical decomposition of the generated solid waste at elevated temperature $\left(350\right.$ to $\left.550^{\circ} \mathrm{C}\right)$ in the absence of oxygen (or any halogen) to produce three fractions which include (Lim et al., 2012):

i. Liquid fraction (often called bio-oil)

ii. Solid (mostly ash) and

iii. Gaseous fractions

Incineration: Incineration is a solid waste treatment technology that encompasses the combustion of organic substance contained in solid waste materials. The heat generated from the process can serve for power generation (El-Emam et al., 2012). Incineration and gasification technologies look similar in principle and operation. However, the energy produced from incineration is higher whereas combustible gas is often the main energy product from gasification.

Constraints to Solid Waste Management in Nigeria: Igbinomwanhia, and Ohwovoriole (2012) reported economic, financial, technical, institutional, social and cultural as the major constraint limiting residential solid waste management in Nigeria. In sub-Sahara Africa countries just like every other developing country has a weak economic base, thus, insufficient funds for development of sustainable solid waste management systems (Ogawa, 1996). Considering the economic requirement of the family in this region, a monthly income of less than or equal to $\$ 300$ cannot meet the economic demand of the family. Hence, they do without the service of a solid waste disposal agent. They simply engaged in crude open dumping of solid waste in drainages, around the streets and open market places, any peace of unused land, open air burning without air pollution control. Besides, economic constraints also make them to patronize cart pushers who are not able to get to the approved designated dump sites where the solid waste are expected to be managed properly.

Generally, solid waste management is given a very low priority in Nigeria and other sub-Sahara Africa. Solid waste management is given very low priority in the budget due to limited finances (Omran, and Read, 2007). As a result, very limited funds are provided to the solid waste management sector by the governments. Thus, the levels of services required for protection of public health and the environment are not 
attained. Also, the user service charges collected by the disposal agents is too little to make any meaningful impact on solid waste management. Besides, users' ability to pay for the services is also limited by their income, and their willingness to pay for the services which are irregular and ineffective is not high either. More so, the end point of the solid waste does provide financial reward to waste disposal agent. Therefore, the only source of finance to the disposal agent is the user service charges.

In Nigeria and other sub-Sahara Africa countries, there is lack of human capitals at both the national and local levels with technical expertise necessary for solid waste management planning and operation (Zavodska, 2003). According to United Nations Commission on Sustainable Development (1997), there is lack of human capitals at both the state and local government level and the private sector with technical expertise necessary for solid waste management planning and implementation. Many officers in charge of solid waste management, particularly at the State Waste Management Board and other agencies handling the issues of waste, have little or no technical background or training in engineering or management. In fact all the problems that the solid waste Management system is faced with are exacerbated by the lack of trained personnel. More so, without adequately trained personnel, sustainable solid waste management planning and implementation is not realizable

Furthermore, the negative perception of the society regarding the work which involves the handling of solid waste is another barrier. Such societal perception leads to low self-esteem for the workers especially the garbage men and in turn produces low working ethics and poor quality of their work. Where the society allows only a certain social class or group to deal with solid waste, the availability of work force for solid waste collection and disposal becomes constrained. Others major challenges facing solid waste management service delivery in Nigeria include (Tobore, 2016);

i. Lack of comprehensive legal framework and enforcement of the existing regulations

ii. Low investment (private) in infrastructure

iii. Inadequate human capacity for

administrative and technical issues

iv. Wrong attitude of the public towards solid waste disposal

v. Cost recovery is low in most states and no funding

vi. Low data management and uncontrolled urbanization

vii. Uncoordinated institutional functions viii. Low academic research and industry linkages

ix. $\quad$ Lack of the needed political will

Conclusion: This research work revealed that enough attention is not given to solid waste management in sub Saharan Africa countries. Challenges facing solid waste management in the study area and various technologies for managing generated solid wastes were identified. The major constraint facing solid waste management includes the lack of technical expertise, finance, culture, etc. Besides, feasible suggestions have been presented for improved solid waste management in the region. However, there is need for urgent attention to be paid to the issue of solid waste management as the adverse environmental effect resulting from the indiscriminate disposal of waste in the region is on the increase.

\section{REFERENCES}

Akintokun, PO; Adekunl, IM; Adekunle, AA; Akintokun, AK; Arowolo, TA (2011). Recycling of organic wastes through composting for land applications, A Nigerian experience. Waste manage. and Res. 29(6): 582-93

Antanasijevic, D; Pocajt, V; Popovic, I; Redzic, N; Ristic, M (2013). The forecasting of municipal waste generation using artificial neural networks and sustainability indicators. Sustain Sci. 8: 37-46

Anwar, J; Habib, A; Haslenda, H; Saeed, IA; Ramli, M. (2014). Municipal Solid Waste Management and Potential Revenue from Recycling in Malaysia. Modern Appl. Sci. 8(4): 37-49

Benjamin, TA, Emmanuel, EO, Gideon, AD (2014). Characterisation of Municipal Solid Waste in the Federal Capital, Abuja, Nigeria. Global J. of Sci. Frontier Res.: Environ. Earth Sci. 14(2): 1-7

El-Emam, RS; Dincer, I; Naterer, GF (2012). Energy and exergy analyses of an integrated SOFC and coal gasification system. Inter. J. of Hydro Ener. 37:1689-97

Fisher, E; Lange, B; Scotford, E (2015). Environment Law (Text, Cases and Materials); Available from: https://books.google.com.ng/books?isbn=019927 0880. Accessed: 10th August 2015.

Forbes Economy ranking in Africa in 2018. Available at http:/www.legit.ng/1192633-fact-check-hasforbes-ranked-nigeria-economy-africa-2018htmi, Accessed 29 ${ }^{\text {th }}$ May, 2019 
Hoornweg, D; Bhada-Tata, P (2012). What a Waste: A Global Review of Solid Waste Management. Urban Development Series Knowledge Papers, World Bank. Available from:http://siteresources.worldbank.org/INTUR BAN DEVELOPMENT/Resources/3363871334852610766/What_a_Waste2012_Final.pdf. Accessed: $5^{\text {th }}$ January, 2016 .

Hoornweg, D; Bhada-Tata, P; Chris, K (2013). Environment Waste production must peak this century. Internal weekly J. of Sci. 502 (7473): 615-617

Hoornweg, D; Thomas, L; Otten, L (2014). Composting and its Application in Developing Countries. Urban Waste Management Urban waste management. Working Paper 8, Urban Development Division, Washington DC, World Bank.

Igbinomwanhia, DI (2011a). Status of Waste Management, Integrated Waste Management. InTech. 2011, Volume II. Available from: http://www.intechopen.com/books/integratedwaste-management-volume-ii/status-of-wastemanagement

Igbinomwanhia DI, Ohwovoriole, Ejovo N (2011b). A Study of the Solid Waste Chain in Benin Metropolis, Nigeria. J. of Appl. Sci. Environ. Manage. 15 (4): 589 - 593

Igbinomwanhia, DI; Ohwovoriole, EN (2012). A Study of the Constraints to Residential Solid Waste Management in Benin Metropolis, Nigeria. J. of Emerg Trends in Engr. and Appl. Sci. 3 (1): 103-107

Igbinomwanhia, DI; Obanor, AI; Olisa, YP (2017). Characterisation of Domestic Solid Waste for the Determination of Waste Management Option in Amassoma, Bayelsa State, Nigeria. J. Appl. Sci. Environ. Manage. 2017. 18(2): 211-215

Kolekara, KA; Hazrab, T; Chakrabartyc, SN (2016). A Review on Prediction of Municipal Solid Waste Generation Models. Int. Conf. on Solid Waste Manage., 5IconSWM 2015, Procedia Environ. Sci. 35:238- 244

Kreiger, MA; Mulder, ML; Glover, AG; Pearce, JM (2014). Life Cycle Analysis of Distribution Recycling of Post-Consumer High Density Polyethylene for 3-D Printing Filament. J. of Cleaner Prod. 70: 90-96
Lim, JS; Manan, ZA; Wan Alwi, SR; Hashim H (2012). A review on utilization of biomass from rice industry as a source of renewable energy. Renew. and Sustainable Ener. Reviews. 16: 30843094

McKendry, P (2002). Energy production from biomass (part 2). Conver. Tech. Bioresource Tech. 83: 47-54

Njiribeako, IA (2003). Management of solid NonBiodegradable waste in Nigeria. Nigerian $J$. of Engr. Manage. 4(2):9-12

Ogawa, H (1996). Sustainable Solid Waste Management in Developing Countries, the 7th ISWA International Congress and Exhibition, Parallel Session 7. Int. Perspective, available at: http://www.gdrc.org/uem/waste/swmfogawa1.htm

Ogweleka, TC (2003). Analysis urban solid waste in Nsuka, Nigeria. The J. of Solid Waste Tech. and Manage., Department of Civil Engineering Widener University, Chester, U.S.A. 29(4)

Ogwueleka, TC (2009). Municipal solid waste characteristics and management in Nigeria. Iran J. of Environ. and Health Sci. Engr. 6(3):173-180.

Omran, A; Read, AD (2007). Waste Not, Want Not" A Study of Household Attitude toward Recycling of Solid Wastes. Environ. Eng. and Manage. J.:18 .

Orhorhorhoro, EK (2014). Performace Study of a Biogas Pilot Plant using Domestic Waste from Benin Metropolis. Master Degree thesis submitted to University of Benin for the award Master Degree in Mechanical Engineering Design and Manufacture

Orhorhoro, EK; Ebunilo, PO; Tamuno, RI; Essienubong, IA (2016a). The Study of Anaerobic Co-Digestion of Non-Uniform Multiple Feed Stock Availability and Composition in Nigeria. Euro. J. of Engr. Rese. and Sci. 1(1): 39-42

Orhorhoro, EK; Ikpe, AE; Tamuno, RI (2016b). Performance Analysis of Locally Design Plastic Crushing Machine for Domestic and Industrial Use in Nigeria. Euro. J. of Engr. Rese. and Sci. 1(2):26-30 
Orhorhoro, EK; Ebunilo, POB; Sadjere, EG (2017a). Determination and Quantification of Household Solid Waste Generation for Planning Suitable Sustainable Waste Management in Nigeria. Inter. J. of Emerg. Engr. Rese. and Tech. 5(8):1-9

Orhorhoro, EK; Ebunilo, POB; Sadjere, EG (2017b). Experimental Determination of Effect of Total Solid (TS) and Volatile Solid (VS) on Biogas Yield. American J. of Modern Ener.3 (6):131-135

Orhorhoro, EK; Ebunilo, POB; Sadjere, EG (2017c). Design of Bio-Waste Grinding Machine for Anaerobic Digestion (AD) System. Euro. J. of Adv. in Engr. and Tech. 4 (7): 560-568

Orhorhoro, EK; Orhorhoro, OW; Atumah, VE (2018a). Performance Evaluation of Design AD System Biogas Purification Filter. Inter. J. Mathematical, Engr. and Manage. Sci. 3(1): 1727

Orhorhoro, EK; Ikpe, AE; Ukwaba, SI (2018b). Effects of Landfill Gas Flow Trajectories at Three Distinct Temperature Phases on the Stress-StrainDisplacement Properties of a Gas Extraction Pipe. J. Appl. Sci. Environ. Manage. 22 (11): $1737-$ 1743

Owamah, IH; Izinyon, OC; Igbinewekan, P (2015). Characteristics and quantification of solid waste generation in the Niger Delta Region of Nigeria: a case study of Ogbe-Ijoih community in Delta State. J. of Mat. Cycl. Waste Manage. 19(1): 366373

Oyelola, OT; Babatunde, AI (2008). Characterization of domestic and market solid wastes at source in Lagos metropolis, Lagos, Nigeria. African J. of Environ. Sci. and Tech. 3 (12): 430-437

Oziegbe, IJ (2015). Design and fabrication of used polyethylene terephthalate bottle washing and sterilizing machine. Master Degree thesis submitted to University of Benin for the award Master Degree in Design and Manufacture.

Pereira, EG; Da Silva, JN; De Oliveira, JL; Machado, CS (2012). Sustainable energy; a review of gasification technologies. Renew. Sustainable Ener. Rev. 16:4753-4762
Titus, EA; Anim, OA (2014). Appraisal of Solid Waste Management Practices in Enugu City, Nigeria. J. Environ. Earth Sci. 4: 98

Sabejeje, AJ; Oketayo, OO; Bello, IJ; Sabejeje, TA (2014). Elemental analysis of leachates from open-dump-solid wastes in Ondo State, Nigeria: Implication on underground water and surface water safety. American J. of Rese. Communication. 2(10):287-296

Thomson, AA (2010). Domestic waste management strategies in Accra, Ghana and other Tropical Developing Nations. Available online;www.academia.edu/2760535/sold_waste_ mgt. 2010

Tobore,

IE

(2016).

Solid Waste Management in Nigeria. Waste Management for Everyone.

Ukwaba, SI; Ikpe, AE; Orhorhoro, EK (2018). Adoption of a landfill system in Nigeria and the role of municipal solid waste segregation on its performance. Nigerian Rese. J. of Engr. and Environ. Sci. 3(1): 280-286

United Nations Commission on Sustainable Development - National Implementation of Agenda 21 (Information Provided by the Government of Nigeria), 1997

United Nation World Population Estimation (2016). Population of Nigeria. http://www.worldometers.info/wordpopulation/nigeria-population/. Accessed September $13^{\text {th }}, 2016$

World Bank (1999). What a Waste: Solid Waste Management in Africa. The World Bank Report. Washington D.C. USA, 1999

World Bank (2003). Thailand Environmental Monitor. A joint publication of the Pollution Control Department, Royal Thai Government. The World Bank, US Asia Environmental Partnership.

Zavodska, A (2003). A study of residential solid waste composition and management in a selected developing country - Guyana. J. Solid Waste Manage. Tech., 29(1) 